\title{
Photosynthetic pigments content and chloroplast characteristics of tamarind leaves in response to different colored shading nets
}

\author{
Joyce Dória Rodrigues Soares ${ }^{1}$, Gabrielen de Maria Gomes Dias ${ }^{2 *}$, Renata Alves Lara Silva ${ }^{1}$, Moacir \\ Pasqual $^{1}$, Claúdia Regina Gontijo Labory ${ }^{3}$, Simone Abreu Asmar ${ }^{4}$, José Darlan Ramos ${ }^{1}$ \\ ${ }^{1}$ Department of Agriculture, Federal University of Lavras, Lavras, Minas Gerais State, Brazil \\ ${ }^{2}$ Rural Development Institute, University of Integration of Lusophone African-Brazilian, Redenção, Ceará State, \\ Brazil \\ ${ }^{3}$ Department of Soil Science, Federal University of Lavras, Lavras, Minas Gerais State, Brazil \\ ${ }^{4}$ Institute of Agricultural Sciences, Federal University of Uberlândia, Uberlândia, Minas Gerais State, Brazil
}

*Corresponding author: gabriellen@gmail.com

\begin{abstract}
The use of coloured shading nets to improve plant development is a technique, which has received considerable recent interest due to positive responses obtained. In this context, photosynthetic pigments content and chloroplast characteristics of tamarind (Tamarindus indica) plants grown under coloured shade nets were examined. Under greenhouse, tamarind seeds were sown in polypropylene trays containing Plantmax ${ }^{\circledR}$ substrate. When the seedlings reached $10 \mathrm{~cm}$ long (approximately $60 \mathrm{~d}$ old), they were placed inside of structures covered with blue, red, white and black shade nets, with $50 \%$ of shading. After $150 \mathrm{~d}$, the leaves were collected and chlorophyll and carotenoids content as well as chloroplast features were assessed. Plants grown under black net showed higher values for chlorophyll a and chlorophyll $b$ content as well as for total chlorophyll and $a / b$ ratio. The black net was also responsible for providing the highest density of chloroplasts and area of starch grains, while the chloroplast area was greater under blue and black nets. These results make the use of black net, a cultivation practice suitable for commercial purposes.
\end{abstract}

Keywords: Tamarindus indica, spectral quality, chlorophyll, carotenoid, seedling formation.

Abbreviations: MS_Murashige \& Skoog, Chl a_chlorophyll a, Chl b_chlorophyll b, cl_chloroplast, g_starch grain, p_cell wall, ei_intercellular space.

\section{Introduction}

Tamarind (Tamarindus indica L., Fabaceae), also known as sweet angle, is a species indigenous to tropical Africa, India and Southeast Asia and was dispersed by men worldwide (Stege et al., 2011). In Brazil, the plants were well adapted and sub spontaneous, being found in scattered plantations, like occurs in Northeast region where tamarind is considered a typical fruit (Souza et al., 2010). This fruit plant is a wellknown multipurpose tree because is used as a food, medicine, wood, fuel forage, and shelter as well as an ideal tree for semi-arid regions due to its tolerance to drought (Reis et al., 2016). The tamarind propagation is predominantly by seeds. However, there are many studies concerning the asexual propagation by cutting, grafting and micropropagation (Huang et al., 2015; Mowobi et al., 2016). Regardless of type of propagation, the plant production in a commercialscale is incipient, being performed without any scientific character (Ferreira et al., 2008). This fact deserves attention since the plant production is one of manners for technical and commercial exploitation of this species. Moreover, tamarind, as a perennial plant, needs a seedling production phase well conducted in order to form plants with high quality and, at the same time, avoid problems that may compromise its exploitation period (Góes et al., 2011).
In literature, one of the most cited alternatives applied for plant production is the manipulation of light quality by using photo-selective nets, commonly known as colored shading nets (Shahak et al., 2004). These nets were designed to selectively filter different spectral bands of solar radiation (Shahak et al., 2009). The intensity and quality of spectrum of radiation play an important role on morphologic and physiologic traits of most of plants, which modify their structure, tissues and organelles to adapt to the new environment (Taiz \& Zeiger, 2013). The plants exposure to different colored nets needs an adjustment of the photosynthetic apparatus to adapt to the new environment. This adaptation involves several responses, such as the leaf anatomy and content of photosynthetic pigments and chloroplasts (Weston et al., 2000). Silva et al. (2015) already reported a successful study about the changes in anatomy of tamarind grown under colored shading nets. However, there is no research about the modifications on pigments content and chloroplasts characteristics of tamarind under these conditions. Taking into consideration that leaves have capacity to arrange their physiology in response to different light conditions, the current paper aimed at evaluating the chlorophyll and carotenoids content as well as chloroplast 
anatomy of tamarind seedlings grown under photo-selective nets.

\section{Results and Discussion}

\section{Carotenoid Pigments}

According to the results obtained from analysis of the accessory pigments of photosynthesis (Table 1) did not reveal the presence of carotenoids in the treatments on colored fabrics.

Although carotenoids are present also in leaves (Taiz and Zeiger, 2013), they appear mostly in the part of the fall when chlorophyll is degraded and provide a yellowish orange color characteristic of this period. Probably the absence of these during the conduct of the experiment (summer), may indicate that the accumulation of carotenoids may not have been the strategy used for protection from damage by light, because, according to Larcher (2004) the relationship between chlorophyll and carotenoids $(\mathrm{Cl} / \mathrm{Car})$ can be used as a potential indicator of oxidative photo losses caused by strong radiation, because the carotenoids can prevent photooxidation of chlorophyll.

\section{Chlorophyll content}

By analysis of data, we observed that the use of colored shading nets resulted in different responses related to chlorophyll content (Table 1). The highest values for chlorophyll $a$, chlorophyll $b$, total chlorophyll as well as $a / b$ ratio were found in the leaves of plants grown under black net. Similar results were related to Catharanthus roseus, which presented improved chlorophyll content under black net, as reported by Melo \& Alvarenga (2009).

Increasing the proportion of the color chlorophyll $b$ and shaded plants can be considered important in shady environments plant adaptability characteristic, since the chlorophyll $b$ absorbs energy at different wavelengths of chlorophyll $a$ and transferred to the reaction center, maximizing, thus captures the energy that effectively operates in photochemical reactions (Taiz and Zeiger, 2013). These observed concentrations of pigments and chloroplast structure changes show an adaptation of the tamarind chromatic variation that aims to improve the photosynthetic performance and infer that control the light radiation can be used in the cultivation of this species to optimize their growth and productivity.

The results are in agreement with Rego and Possamar (2006), who observed higher chlorophyll $b$ in higher levels of shading the tree species Cariniana legalis. The ability to grow quickly when moderately shaded is an important mechanism of adaptation of the species, constituting an avoidance strategy to low and high light intensity. Adaptation to low luminosities is a genetic trait, which causes the leaves show anatomical structure and physiological properties that enable the effective use of the available solar radiation. According to Larcher (2004), ecologically, changes in chlorophyll biosynthesis by spectral variations could deliver benefits for growth and reproductive success of the plant species. Thus, the results indicate the occurrence of a chromatic adaptation of tamarind possibly assist in their photosynthetic performance, because the increase in the content of chlorophyll $b$ in black mesh may help the photosynthetic performance by transferring the absorbed energy to chlorophyll $a$, avoiding thus photoinhibition because chlorophyll $b$ acts as sunscreen molecule through the rapid dissipation of the excited states of chlorophyll.
The study aimed to characterize culture conditions that facilitate changes in the photosynthetic apparatus tamarind, since these are closely associated with the capture light energy and production of metabolites used for the growth and development of the plant.

\section{Chloroplast characteristics}

The number of chloroplasts per cell varied among the plants under different environments treatments (Table 2).

Cultivation under black mesh provided $40 \%$ reduction in the number of chloroplasts per cell compared to the other treatments. Martins et al. (2010) found Ocimum gratissimum $60 \%$ reduction in the number of chloroplasts under cultivation black screen, which according to the results of the present study confirm that the chloroplast biogenesis can be controlled by changes in the spectral quality of the radiation in the environment of cultivation. According to Jiao et al. (2007) and Ruckle et al. (2007) for the biosynthesis of the chloroplast route of signal transduction involves cryptochromes sensitive to variations in the content of the total light radiation.

\section{Chloroplasts analysis by transmission electron microscopy}

The influence of quality and quantity of light for plant growth interfere in different ways among species. In the synthesis of chloroplast starch grains occurs and these showed a larger area in plants grown under tamarind black mesh (Fig. 1 and Table 2).

Lower values were found in plants under blue, red and white meshes, respectively, indicating that the spectral quality disadvantage area in the starch grains present in the chloroplast. Brant et al. (2010) noted an increase in area of the starch grains in the cultivation of Melissa officinalis in black mesh. However, Costa et al. (2007) concluded that there was no difference between treatments for the area of the starch grains of Ocimum selloi. In the present study, the reduction in the number of chloroplasts in black mesh was accompanied by an increase in area of chloroplasts (23.31 $\mathrm{mM}$ ), the environment of black mesh provided higher chloroplasts and outnumbered, with an advantageous feature for growth of tamarind.

\section{Materials and Methods}

\section{Plant material and experimental conditions}

Tamarind seeds were collected from adult plants located in Coronel Murta city, northern Minas Gerais State, Brazil. The collected material was taken to Lavras city, Minas Gerais $\left(21^{\circ} 14 \mathrm{~S} ; 45^{\circ} 00^{\prime} \mathrm{W}, 918 \mathrm{~m}\right.$ a.s.l.) to perform the experiment. According to Köppen classification, Lavras presents a regional climate classified as Cwa, i.e., a dry cold season from April to September and a warm and wet season from October to March (Brasil, 1992).

The seeds were sown in polypropylene trays containing Tropstrato ${ }^{\circledR}$ substrate and they were kept in a growth chamber at $30^{\circ} \mathrm{C}$ for $60 \mathrm{~d}$. After $60 \mathrm{~d}$, the seedlings $(10 \mathrm{~cm}$ long) were transplanted into $2 \mathrm{~L}$ pots filled with the same substrate used for germination. The pots were placed inside of structures covered with 'colored-ColorNets' (blue and red - Chromatinet ${ }^{\circledR}$ ) and 'neutral-ColorNets' (white and black), with shading intensity of $50 \%$. Polysac Plastic Industries ${ }^{\circledR}$ (Nir-Yitzhak, Israel) provided all nets.

Each treatment consisted of 20 seedlings (one plant per pot) in a $20 \times 20 \mathrm{~cm}$ spacing. Plants were maintained at field 
Table 1. Contents of chlorophyll $a(\mathrm{Chl} a)$, chlorophyll $b(\mathrm{Chl} b)$, total chlorophyll (Total chl), $a / b$ ratio, and total carotenoid (Total carot) in leaves of tamarind grown under different coloured shading nets. Values are given in $\mathrm{mg} \mathrm{g}^{-1}$ fresh weight.

\begin{tabular}{lccccc}
\hline Net & Chl a & Chl b & Total chl & a/b ratio & Total carot \\
\hline White & $7.98 \mathrm{~d}$ & $2.30 \mathrm{c}$ & $10.27 \mathrm{~d}$ & $0.45 \mathrm{c}$ & -- \\
Blue & $8.28 \mathrm{c}$ & $14.04 \mathrm{~b}$ & $22.78 \mathrm{c}$ & $0.58 \mathrm{~b}$ & - \\
Red & $9.91 \mathrm{~b}$ & $16.88 \mathrm{~b}$ & $26.78 \mathrm{~b}$ & $0.58 \mathrm{~b}$ & -- \\
Black & $10.10 \mathrm{a}$ & $22.69 \mathrm{a}$ & $31.11 \mathrm{a}$ & $3.46 \mathrm{a}$ & - \\
\hline \multicolumn{5}{l}{}
\end{tabular}

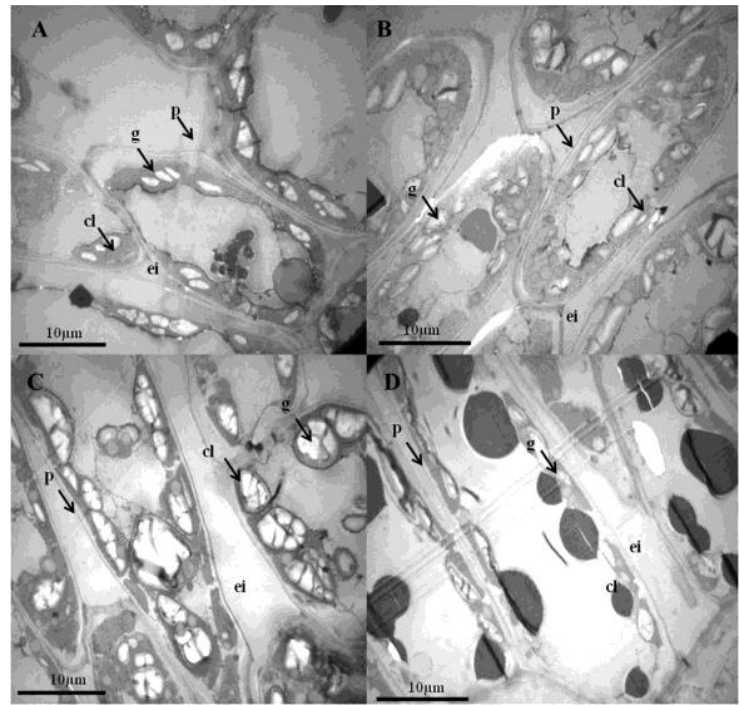

Fig 1. Electro micrographs of the sections of tamarind leaves grown under red (A), white (B), blue (C) and black (D) nets, showing chloroplasts and starch grains in the cells of the palisade parenchyma. $\mathrm{cl}=$ chloroplast, $\mathrm{g}=$ starch grain, $\mathrm{p}=$ cell wall and ei $=$ intercellular space. Bar $=10 \mu \mathrm{m}$.

Table 2. The effects of coloured shading nets on chloroplast density $\left(\right.$ cell $\left.\mu \mathrm{m}^{-2}\right)$, chloroplast area $\left(\mu \mathrm{m}^{2}\right)$ and starch grains area $\left(\mu \mathrm{m}^{2}\right)$ of leaves of tamarind.

\begin{tabular}{lccc}
\hline Net & Chloroplast density & Chloroplast area & Starch grains area \\
\hline White & $12.7 \mathrm{a}$ & $12.59 \mathrm{~b}$ & $6.37 \mathrm{c}$ \\
Blue & $13.7 \mathrm{a}$ & $20.31 \mathrm{a}$ & $17.21 \mathrm{~b}$ \\
Red & $11.7 \mathrm{a}$ & $13.76 \mathrm{~b}$ & $7.50 \mathrm{c}$ \\
Black & $9.0 \mathrm{~b}$ & $23.31 \mathrm{a}$ & $20.5 \mathrm{a}$ \\
\hline
\end{tabular}

capacity throughout the experiment by daily irrigation. The evaluations were carried out after $150 \mathrm{~d}$ under colored nets.

\section{Pigments content}

Pigments content were determined using the procedure proposed by Lichtenthaler (2001). Seven fully expanded leaves situated on $4^{\circ}$ node below the plant apex were collected randomly. Leaves were packed in aluminum foil and maintained inside a styrofoam box with ice cubes. The material was brought to laboratory to extract and quantify the pigments. Samples consisted of $2 \mathrm{~g}$ of fresh leaves were macerated in $50 \mathrm{~mL} 80 \%$ acetone. Chlorophyll a, chlorophyll $\mathrm{b}$ and carotenoids concentrations were measured photometrically in quartz cuvettes. The concentrations of pigments were calculated using the following equations given by Lichtenthaler, 2001 :

$\mathrm{C}_{\mathrm{a}}\left(\mu \mathrm{g} \mathrm{mL} \mathrm{L}^{-1}\right)=12.25 \mathrm{~A}_{663}-2.79 \mathrm{~A}_{645}$

$\mathrm{C}_{\mathrm{b}}\left(\mu \mathrm{g} \mathrm{mL} \mathrm{mL}^{-1}\right)=21.50 \mathrm{~A}_{645}-5.10 \mathrm{~A}_{663}$

$\mathrm{Ct}\left(\mu \mathrm{g} \mathrm{mL}^{-1}\right)=\left(1000 \mathrm{~A}_{470}-1.82 \mathrm{c}_{\mathrm{a}}-85.02 \mathrm{c}_{\mathrm{b}}\right) / 198$

where $\mathrm{A}_{663}, \mathrm{~A}_{645}$ and $\mathrm{A}_{470}$ are the absorbance at wave lengths 663, 645 and $470 \mathrm{~nm}$, respectively. $\mathrm{Ca}, \mathrm{Cb}$ and $\mathrm{Ct}$ are the concentrations of chlorophyll a, chlorophyll $b$ and carotenoids in plant extract in micrograms per milliliter, respectively.

\section{Chloroplasts analysis by transmission electron microscopy}

Collected leaf fragments $\left(0.5 \mathrm{~cm}^{2}\right.$ in size $)$ were fixed with $2.5 \%$ paraformaldehyde and $2.5 \%$ glutaraldehyde in $0.05 \mathrm{M}$ cacodylate buffer, $\mathrm{pH}$ 7.0, during four hours at room temperature. After wash in $0.05 \mathrm{M}$ cacodylate buffer, the fragments were post-fixed in $1 \% \mathrm{OsO}_{4}$ in the same buffer for 4 hours. The material was dehydrated in a series of increasing concentrations of acetone and embedded in Spurr resin. Thin $(1 \mu \mathrm{m})$ and ultrathin $(<100 \mathrm{~nm})$ sections were cut using ultramicrotome Reichrt-Jung. Thin sections were stained with toluidine blue, and then set in Permalt medium permanently for evaluating the density and area of chloroplasts in palisade parenchyma cells with an Olympus CBB microscope. Meanwhile, ultrathin sections were collected on gold grids and dried in aluminum raques covered with formvar (Rowley and Moran, 1975).

The sections were post-contrasted in uranyl acetate, followed by lead acetate, and then examined in a transmission electron microscope Zeiss-EM 109. In ultrastructural analyzes, we evaluated the area of starch grains in palisade parenchyma cells. 


\section{Statistical analysis}

The experiment was arranged in a completely randomized design, with 4 treatments and 20 replicates. Data were subjected to analysis of variance and, in occurrence of significance, means were compared by Scott-Knott test $(P \leq$ $0.05)$.

\section{Conclusion}

The use of colored shading nets modifies the pigments content and chloroplasts characteristics of tamarind seedlings. Better values are obtained when black net is preferred for cultivation. These results can be incorporated into culture practices for plant production. However, more research is required for understanding the process behind plant responses under different environments.

\section{Acknowledgments}

The authors wish to thank National Council for Scientific and Technical Development (CNPq), Coordination of Improvement of Higher Education Personnel (CAPES) and the Foundation for Support of Research in Minas Gerais (FAPEMIG) for funding this research.

\section{References}

Brant RS, Pinto JEBP, Rosa LF, Albuquerque CJB, Ferri PH, Corrêa RM (2010) Growth, content and composition of lemon balm essential oil cultivated under color shading net. Cienc Rural. 39:1401-1407.

Brasil (1992) Ministério da Agricultura e Reforma Agrária. Normais climatológicas de 1961- 1990. Brasília, 84p.

Costa LCB, Castro EM, Pinto JEBP, Alves E, Bertolucci SRV, Rosal LF, Moreira CM (2007) Aspectos da anatomia foliar de Ocimum selloi Benth. (Lamiaceae) em diferentes condições de qualidade de luz. Rev Bras Biocienc. 5:6-8.

Costa WD, Loiola LCO, Nonato CFA, Andrade CC, Costa JGM, Rodrigues FFG (2015) Physicochemical, bromatological and antibacterial analysis of Tamarindus indica Linn fruits. Caderno Cult Cienc. 14:86-95.

Duke SO, Kenyon WH (1986) Effects of dimethazone (FMC 57020) on chloroplast development II. Pigment synthesis and photosynthetic function in cowpea (Vigna unguiculata L.) primary leaves. Pestic Biochem Phys. 25:11-18.

Ferreira EA, Mendonça V, Souza HA, Ramos JD (2008) Phosphate and potassic fertilization on seedling production of tamarind fruit. Sci Agrar. 9:475-480.

Góes GB, Dantas DJ, Araújo WBM, Melo IGC, Mendonça V (2011) Use of earthworm castings as a substrate for the production of seedlings of tamarind. Rev Verde 6:125-131.

Huang D, Li J, Lin F, Xu Y, Ma W, Li Y, Li Y, Song S, Wang B (2015) Optimal system of fast propagation for tamarind cotyledon nodes via tissue culture. Bangladesh J Bot. 44:851857.

Jiao Y, Lau OS, Deng XW (2007) Light-regulated transcriptional networks in higher plants. Nat Rev Genet. 8:217-230.

Komutarin T, Azadi S, Butterworth L, Keil D, Chitsomboo BN, Suttajit M, Meade BJ (2004) Extract of the seed coat of Tamarindus indica inhibits nitric oxide production by murine macrophages in vitro and in vivo. Food Chem Toxicol. 42:649658.

Lichtenthaler HK, Buschmann C (2001) Chlorophylls and carotenoids: measurement and characterization by UV-VIS spectroscopy. Curr Protocols Food Anal Chem.

Martins JR, Alvarenga AA, Castro EM, Silva APO, Alves E (2010) Pigments content and alfavaca-cravo chloroplast structure cultivated under colored nets. Cienc Rural. 40:64-69.
Melo AAM, Alvarenga AA (2009) Shading of 'Pacifica White' Catharanthus roseus (L.) G. Don plants with colored nets: vegetative development. Cienc Agrotec. 33:514-520

Morini S, Muleo R (2003) Effects of light quality on micropropagation of woody species. In: Jain, S.M.; K. Ishii. Micropropagation of woody trees and fruits. Dordrecht: Kluwer Academic Publishers, 3-35.

Mowobi GG, Osuji C, Salisu A, Yahaya FM (2016) In vitro regeneration of Tamarind (Tamarindus indica L.) explants. J Environ Life Sci. 1:26-31.

Oliveira GC, Vieira WL, Bertolli SC, Pacheco AC (2016) Photosynthetic behavior, growth and essential oil production of Melissa officinalis L. cultivated under colored shade nets. Chil J Agr Res. 76:123-128.

Oren-Shamir M, Gussakovsky EE, Shpiegel E, Nissim-Levi A Ratner K, Ovadia R, Giller YE, Shahak Y (2001) Coloured shade nets can improve the yield and quality of green decorative branches of Pittosphorum variegatum. J Hortic Sci Biotech. 76:353-361.

Rego GM, Possamai E (2006) Efeito do sombreamento sobre o teor de clorofila e crescimento inicial de jequitibá-rosa. Bol Pesq Florest. 53:179-194.

Reis PMCL, Dariva C, Vieira GAB, Hense H (2016) Extraction and evaluation of antioxidante potential of the extracts obtained from tamarind seeds (Tamarindus indica), sweet variety. J Food Eng. 173:116-123.

Rowley CR, Moran DT (1975) A simple procedure for mounting wrinkle-free section on formvar-coated slot grids. Ultramicroscopy. 1:151-155.

Shahak Y, Gussakovsky EE, Gal E, Ganelevin R (2004) Colornets: crop protection and light-quality manipulation in one technology. Acta Hortic. 659:143-151.

Shahak Y (2008) Photo-selective netting for improved performance of horticultural crops. A review of ornamental and vegetable studies carried out in Israel. Acta Hortic. 770:161-168.

Shaver DJ, Oldenburg DJ, Bendich A (2008) The structure of chloroplast DNA molecules and the effects of light on the amount of chloroplast DNA during development in Medicago truncatula. Plant Physiol. 146:1064-1074.

Silva GG, Praça EF, Junior JG, Rocha RHC, Costa ML (2000) Caracterização física e química de tamarindo (Tamarindus indica L.) em diferentes estádios de maturação. Rev Bras Fruti. 22:291-293

Silva RAL, Soares JDR, Dias GMG, Pasqual M, Chagas EA, Gavilanes ML (2015) Tamarind cultivation under colored shading nets: leaf anatomical plasticity. Cienc Rural. 45:238244.

Souza MD, Fernandes RR, Pasa MC (2010) Estudo etnobotânico de plantas medicinais na comunidade São Gonçalo Beira Rio, Cuiabá, MT. Biodiversidade 9:91-100.

Souza GS, Castro EM, Soares AM, Santos AR, Alves E (2011) Photosynthetic pigments content, photosynthesis rate and chloroplast structure in young plants of Mikania laevigata Schultz Bip. ex Baker grown under colored nets. Semin-Cienc Agrar. 32:1843-1854.

Stege CVD, Prehsler S, Hartl A, Vogl CR (2011) Tamarind (Tamarindus indica L.) in the traditional West African diet: not just a famine food. Fruits 66:171-185.

Taiz L, Zeiger E (2013) Plant physiology. 5 ed. Porto Alegre: Artmed, $918 \mathrm{p}$

Weston E, Thorogood K, Vinti G, López-Juez E (2000) Light quantity controls leaf-cell and chloroplast development in Arabidopsis thaliana wild type and blue-lightperception mutants. Planta. 211:807-815. 